\title{
PERANAN KEMAMPUAN VERBAL DAN KEMAMPUAN NUMERIK TERHADAP KEMAMPUAN BERPIKIR KRITIS MATEMATIKA
}

\author{
Ari Irawan ${ }^{1)}$, Gita Kencanawaty ${ }^{2)}$ \\ ${ }^{1), 2)}$ Program Studi Teknik Informatika, Universitas Indraprasta PGRI \\ Email: mascan_89@yahoo.com ${ }^{1)}$ dan gita_kencanawaty@yahoo.com ${ }^{2)}$
}

\begin{abstract}
The purpose of this study to see the effect of verbal and numerical skills on critical thinking skills of mathematics, verbal ability to influence critical thinking skills of mathematics, numerical ability to influence critical thinking ability in mathematics. The method used is a survey where given a test of verbal ability, numerical kemamuan math and critical thinking skills. This research sample MIA class XI students in high schools in the city of Depok representing each district taken as many as 9 schools with a total sample of 360 respondents. Hypothesis testing using two-way ANOVA. Results of the study showed there are significant verbal and numerical ability jointly to the critical thinking skills of mathematics, there is the influence of the verbal skills of critical thinking skills matametika, there is the influence of numerical ability of the critical thinking skills of mathematics.
\end{abstract}

Keywords: verbal, numerical, critical thinking, math

\section{PENDAHULUAN}

Pedidikan merupakan hak dari setiap warga negara dan ini telah diatur dalam Undang-Undang.Namun pada kenyataanya masih saja ada anak-anak di negara kita belum mendapatkan pendidikan yang layak. Maka dari itu pemerintah membuat suatu kebijakan pendidikan yaitu wajib belajar 9 tahun yang terdiri dari enam tahun sekolah dasar dan tiga tahun sekolah menengah pertama.Pendidikan juga harus dilakukan secara merata diseluruh Indonesia jangan hanya terpusat pada Jakarta dan pulau jawa saja.

Dalam proses pendidikan perlu adanya kreasi dan inovasi bagi guru untuk membuat pembelajaran menjadi lebih bermakna dan menyenangkan. Mata pelajaran matematika selalu menjadi momok yang menakutkan bagi sebagian besar peserta didik. Hal ini menjadi tantangan bagi guru matematika untuk menghilangkan paradigma seperti itu dengan menyajikan materi-materi ajar menyenangkan dan menambah gairah peserta didik untuk lebih termotivasi mempelajari matematika.

Jika dilihat dari tingkatannya pada saat SMA inilah peserta didik sudah mulai mencurahkan pikirannya untuk berpikir lebih baik dan keras lagi dalam memecahkan suatu permasalahpermasalahan yang dialaminya. Maka dari pada tingkatan SMA ini perlu adanya arahan dari guru tentang kemampuan berpikir kritisnya seperti dengan melakukan analisa studi kasus dan sebagainya. Namun pada kenyataannya masih banyak peserta didik yang belum memahami tentang pentingnya berpikir kritis matematika. Oleh karena itu perlu adanya kajian tentang kemampuan berpikir kritis matematika.

Masih banyaknya peserta didik yang tidak mengatahui tentang kemampuan dan potensi pada dirinya menyebabkan peserta didik kurang 
merasa percaya diri untuk menguangkan gagasan, kritikan terhadap hal-hal yang mereka pahami namun belum berani untuk mengungkapkannya.Oleh karena itu menjadi penting adanya peserta didik mengetahui potensi dan kemampuan yang dimilikinya.Atas dasar itulah peneliti mencoba mencari tahu tentang faktor-faktor yang dapat mempengaruhi kemampuan berpikir kritis matematika pada peserta didik tingkat sekolah menangah atas.Dalam hal ini peneliti melihat ada hal yang mendasari kemampuan berpikir kritis matematika yaitu adanya kemampuan verbal dan kemampuan numerik.

Masih rendahnya nilai yang dimilki oleh siswa perlu adanya kajian tentang hal-hal yang dapat meningkatkan nilai tersebjut yatu salah satunya dengan meningkatkan kemampuan berpikir kritisnya. Karena dengan peningkatan kemampuan berpikir kritisnya maka akan dapat meningkatkan hasil belajar yang dimiliki oleh siswa. salah satu cara untuk meningktakan kemampuan berpikir kritisnya adalah dengan mengetahui kemampuan verbal dan kemampuan numerik yang dimilki oleh siswa dengan melakukan pelatihan tentang kemampuan numerik dan verbal tersebut dengan laitiah soal-sial sehingga kemampuan berpikir kritis matematika akan semakin meningkat yang berimbas pada peningkatan hasil belajar siswa. Maka dengan ini peneliti mengambil judul pengaruh kemampuan verbal dan kemampuan numerik terhadap kemampuan berpikir kritis matematika.

Berpikir kritis adalah aplikasi membuat sebuah alasan yang bersifat hati-hati dalam penentuan apakah pendapat itu benar atau sebaliknya atau berpikir kritis itu adalah perubahan pendapat (Leonard, 2013). Dari pendapat diatas maka dapat disimpulkan kemampuan berpikir kritis matematika adalah kemampuan melihat suatu persoalan matematika secara hati-hati dan pengambilan suatu keputusan apakah hal yang diambil itu benar atau tidak.

Kemampuan berpikir kritis adalah suatu kemampuan yang dimiliki seseorang dalam menyelesaikan suatu persoalan secara efektif dengan argument yang ada membantu seseorang untuk menganalisis, mengevaluasi, serta mengambil keputusan tentang apa yang diyakini atau dilakukan (Irawan, 2014). Dari pendapat tersebut maka disimpulkan kemampuan berpikir kritis matematika adalah suatu kemampuan yang dimiliki oleh seseorang atau peserta didik untuk menganalisis sebelum mengambil keputusan yang tepat dapat pembelajaran matematika.

Kemampuan berpikir kritis adalah suatu proses penggunaan kemampuan berpikir secara efektif yang dapat membantu seseorang untuk membuat, mengevaluasi, serta mengambil keputusan tentang apa yang diyakini atau dilakukan (Prahati, 2011). Dari pengertian diatas maka dapat disimpulkan kemampuan berpikir kritis matematika adalah suatu kemampuan berpikir yang efektif fdan efisien untuk mengevalasi dan mengambil keputusan terhadap apa yang diyakininya.

Berpikir kritis adalah proses berpikir untuk menyusun, mengorganisasikan, mengingat dan menganalisis argumen dan memberikan interpretasi berdasarkan persepsi yang sahih logical reasoning (Dona, 2010). Dari pengertian diatas maka dapat disimpulkan kemampuan berpikir matematika adalah kemampuan untuk menyusun dan mengingat serta menganalisis masalah matematika.

Dari pendapat-pendapat di atas dapat disimpulkan kemampuan berpikir 
kritis matematika adalah sutu kemampuan berpikir yang efektif dan efisien untuk menganalisa dan memecahkan permasalahan menganalisis, mengevaluasi, serta mengambil keputusan tentang apa yang diyakini atau dilakukan yang berkaitan dengan pelajaran matematika. Maka dari itu kemampuan berpikir kritis matematika merupakan hal yang sangat penting bagi peserta didik untuk lebih dapat mengembangkan diri dalam berpikir ktitis.

Kemampuan verbal adalah kemampuan menjelaskan pemikiran atau kemampuan mengaitkan berbagai informasi yang diperoleh dan membuat hipotesis (Levy dan Ransdell, 1996 dalam Kumara, 2001). Dari pengetian diatas maka dapat disimpulkan kemampuan verbal adalah kemampuan yang dimiliki seseorang untuk menjelaskan pemikirannya dan mengaitkan informasi yang diperolehnya serta dapat membuat suatu hipotesis.

Kemampuan verbal yang baik diduga memiliki kecakapan yang mensyaratkan keakraban dengan bahasa tertulis maupun lisan untuk menyimak, menelaah isi dari suatu pernyataan, berani mengungkapkan ide, gagasan, pendapat, dan pikirannya,sehingga siswa tersebut dapat mengambil suatu kesimpulan yang tepat (Saregar dkk, 2013)

Kemampuan verbal adalah kemampuan penalaran tentang analogi verbal yang penekanannya tertuju pada komponen penalaran bukan pada kesulitan kata-kata (Simbolon, 2014). Dari pengertian di atas maka dapat disimpulkan kemampuan verbal adalah kemampuan untuk memberikan penalaran dalam bahasa.

Dari uraian-uraian diatas maka dapat disimpulkan kemampuan verbal adalah kemampuan menganalisa bahasa yang dilkukan oleh seseorang untuk menterjemahkannya ke dalam bentuk lain sehingga menjadi lebih mudah untuk dimengerti.

Kemampuan numerik dimaksudkan adalah kemampuan berpikir, mengorganisasi informasi untuk menyelesaikan masalah yang berkaitan dengan angka. Kemampuan numerik meliputi kemampuan menghitung dalam hal penjumlahan, kemampuan menghitung dalam hal pengurangan, kemampuan menghitung dalam hal perkalian, dan kemampuan menghitung dalam hal pembagian. Kemampuan numerik dapat ditingkatkan melalui latihan-latihan secara teratur dan mencoba berbagai macam hitungan sehingga pada akhirnya dapat menemukan cara-cara baru dalam kalkulasi bilangan (Sumada, dkk, 2013).

Dari pengertian di atas maka dapat simpulkan bahwa kemampuan numerik adalah kemampuan seseorang untuk memecahkan permasalahan yang berkaitan dengan angka-angka. Selain itu kemampuan numerik juga adalah kemampuan untuk menghitung atau mengkalkulasikan, kemampuan numerik dapat ditingkatakn dengan cara latihan-latihan secara teratur dan terarah.

Kemampuan numerik merupakan kemampuan standar tentang angka dan kemampuan melakukan perhitungan-perhitungan yang juga merupakan bagian dari aktivitas matematika (Saeful, 2014). Kemampuan numerik merupakan kemampuan yang berkaitan dengan kecermatan dan kecepatan dalam penggunaan fungsi-fungsi hitung dasar. Maka dari itu kemampuan numerik merupakan suatu kemampuan yang berkaitan dengan cepat dan tepat dalam melakukan perhitungan operasi hitung dasar matematika (Astuti dkk, 2013). 
Kemampuan numerik adalah kemampuan dalam menggunakan angka-angka dan penalaran (logika) meliputi bidang matemtika, mengklasifikasikan dan mengkategorikan informasi, berpikir dengan konsep abstrak untuk menemukan hubungan antara suatu hal dengan hal lainya (Irawan, 2014). Dari pengertian diatas maka dapat disimpulkan bahwa kemampuan numerik adalah kemampuan seseorang dalam menggunakan angka-angka setelah orang tesebut memberikan klasifikasi dengan konsep-konsep abstrak yang dimilikinya.

Kemampuan numerik yaitu kemampuan yang berhubungan dengan angka dan kemampuan untuk berhitung (Rosida dkk, 2002). Dari pengertian diatas maka dapat disimpulkan kemampuan numerik adalah kemampuan seseorang untuk melakukan perhitungan dengan angkaangka.

Berdasarkan uraian-uraian
pengertian di atas maka dapat
disimpulkan kemampuan numerik
adalah kemampuan yang dimiliki oleh
seseorang untuk menggunakan angka-
angka, melakukan perhitungan dan
merubah permasalahan uraian cerita
menjadi angka-angaka yang selanjutnya
dapat dilakukan perhitungan dengan
matematika.

\section{METODE PENELITIAN}

Metode yang digunakan dalam penelitian ini adalah survei. Sampel penelitian ini berjumlah sebanyak 360 siswa yang berasal dari 9 sekolah negeri yang mewakili masing-masing kecamatan yang ada di kota Depok, dapat dilihat pada Tabel 1 .

Tabel 1. Jumlah Sampel Responden Penelitian

\begin{tabular}{cllc}
\hline No & \multicolumn{1}{c}{ Nama Sekolah } & Kecamatan & Jumlah Sampel \\
\hline 1. & SMAN 3 Depok & Sukmajaya & 40 \\
2. & SMAN 5 Depok & Sawangan & 40 \\
3. & SMAN 6 Depok & Limo & 40 \\
4. & SMAN 7 Depok & Tapos & 40 \\
5. & SMAN 8 Depok & Cilodong & 40 \\
6. & SMAN 9 Depok & Cinere & 40 \\
7. & SMAN 11 Depok & Beji & 40 \\
8. & SMAN 12 Depok & Cipayung & 40 \\
9. & SMAN 13 Depok & Cimanggis & 40 \\
\multicolumn{4}{c}{ Jumlah Responden } \\
\hline
\end{tabular}

Pengambilan data dilakukan dengan cara memberikan instrumen tes kepada sampel penelitian pada masingmasing variabel yaitu kemampuan verbal, kemampuan numerik, dan kemampuan berpikir kritis matematika. Tes yang digunakan sebelumnya di uji validitas dan reliabilitas sehingga di dapat banyaknya item soal yang digunakan untuk uji kemampuan numerik dan kemampuan verbal masing-masing sebanyak 25 item soal pilihan ganda. Dan untuk kemampuan numeriknya ada 8 soal yang valid untuk digunakan sebagai alat ukur kemampuan berpikir kritis matematika. Teknik pengolahan data dengan menggunakan anova dua jalur. Namun sebelumnya dilakukan pengujian normalitas, homogenitas, linieritas dan multikolinieritas.

\section{HASIL PENELITIAN DAN PEMBAHASAN}

Pengujian normalitas menggunakan One Sample Kolmogrov Smirnov Test yang dapat dilihat pada Tabel 2 . 
e-ISSN 2442-5419 Vol. 5, No. 2 (2016) 110-119

p-ISSN 2089-8703

Tabel 2. Hasil Uji Normalitas

\begin{tabular}{llr}
\hline & & Unstandardiz Ed Residual \\
\hline $\mathrm{N}$ & & 360 \\
Normal Parameters* & Mean & 0,000000 \\
& Std. Deviation & 11,24124091 \\
Most Extreme Differences & Absolute & 0,043 \\
& Positive & 0,033 \\
& Negative &,- 043 \\
Kolmogrov-Smirnov Z & &, 819 \\
Asymp Sig (2-tailled) & &, 514 \\
\hline
\end{tabular}

a. Test distirbution is Normal

Dari hasil pengujian normalitas untuk keseluruhan kelompok data di dapat 0,514>0,05 maka kelompok data berdistribusi normal. Pengujian homogenitas antara kemampuan

Tabel 3. Hasil Uji Homogenitas

\begin{tabular}{lrrrc}
\hline & Levene Statistic & df1 & df2 & Sig. \\
\hline $\mathrm{X}_{1}$ Pada Y & 1,783 & 19 & 340 & 0,130 \\
$\mathrm{X}_{2}$ Pada Y & 1,726 & 19 & 340 & 0,112 \\
\hline
\end{tabular}

Berdasarkan Tabel 3 didapat nilai signifikansi untuk uji homogenitas kemampuan berpikir kritis matematika pada kemampuan verbal adalah 0,130 dan untuk pengujian homogenitas kemampuan berpikir kritis matematika pada kemampuan numerik adalah 0,112. Karena kedua nya lebih besar dari 0,05

berpikir kritis matematika pada kemampuan verbal. Dan uji homogentias kemampuan berpikir kritis matematika pada kemampuan numerik.

Tabel 4. Hasil Uji Linieritas Kemampuan Verbal terhadap Kemampuan Berpikir Kritis Matematika

ANOVA Table

\begin{tabular}{|c|c|c|c|c|c|c|c|}
\hline & & & $\begin{array}{l}\text { Sum of } \\
\text { Squares }\end{array}$ & df & $\begin{array}{l}\text { Mean } \\
\text { Square }\end{array}$ & $\mathrm{F}$ & Sig. \\
\hline \multirow{5}{*}{$\begin{array}{l}\text { Kemampuan } \\
\text { Berpikir Kritis } \\
\text { Matematika * } \\
\text { Kemampuan } \\
\text { Verbal }\end{array}$} & Between & (Combined) & 11286,924 & 19 & 594,049 & 4,956 & 0,000 \\
\hline & Groups & Linearity & 4494,717 & 1 & 4494,717 & 37,500 & 0,000 \\
\hline & & $\begin{array}{l}\text { Deviation } \\
\text { from } \\
\text { Linearity }\end{array}$ & 6792,208 & 18 & 377,345 & 3,148 & 0,072 \\
\hline & \multicolumn{2}{|c|}{ Within Groups } & 40752,451 & 340 & 119,860 & & \\
\hline & \multicolumn{2}{|l|}{ Total } & 52039,375 & 359 & & & \\
\hline
\end{tabular}


Hasil uji linieritas antara kemampuan verbal dengan kemampuan berpikir kritis matematika didapat 0,072. Karena lebih dari 0,05 maka dapat dikatakan bahwa kemampuan verbal terhadap kemampuan berpikir krirtis matematika bersifat linier.

Tabel 5. Hasil Uji Linieritas Kemampuan Numerik terhadap Kemampuan Berpikir Kritis Matematika

\begin{tabular}{|c|c|c|c|c|c|c|c|}
\hline \multicolumn{8}{|c|}{ ANOVA Table } \\
\hline & & & $\begin{array}{l}\text { Sum of } \\
\text { Squares }\end{array}$ & df & $\begin{array}{l}\text { Mean } \\
\text { Square }\end{array}$ & $\mathrm{F}$ & Sig. \\
\hline \multirow{5}{*}{$\begin{array}{l}\text { Kemampuan } \\
\text { Berpikir Kritis } \\
\text { Matematika * } \\
\text { Kemampuan } \\
\text { Numerik }\end{array}$} & \multicolumn{2}{|c|}{ Between (Combined) } & 9236,008 & 19 & 486,106 & 3,861 & 0,000 \\
\hline & Groups & Linearity & 2971,121 & 1 & 2971,121 & 23,601 & 0,000 \\
\hline & & $\begin{array}{l}\text { Deviation } \\
\text { from } \\
\text { Linearity }\end{array}$ & 6264,887 & 18 & 348,049 & 2,765 & 0,061 \\
\hline & \multicolumn{2}{|c|}{ Within Groups } & 42803,367 & 340 & 125,892 & & \\
\hline & \multicolumn{2}{|l|}{ Total } & 52039,375 & 359 & & & \\
\hline
\end{tabular}

Berdasarkan Tabel 5 Di atas untuk uji linieritas kemampuan numerik dengan kemampuan berpikir kritis matematika di dapat 0,061. Keduanya lebih dari 0,05 maka dapat dikatakan masing-masing bersifat linier.

Selanjutnya dilakukan uji multikolinieritas antar masing-masing variabel bebasnya yaitu kemampuan verbal dan kemampuan numerik di dapat pada Tabel 6 dibawah ini:

Tabel 6. Hasil Uji Multikolonieritas Kemampuan Verbal dan Kemampuan Numerik Coefficients $^{\mathbf{a}}$

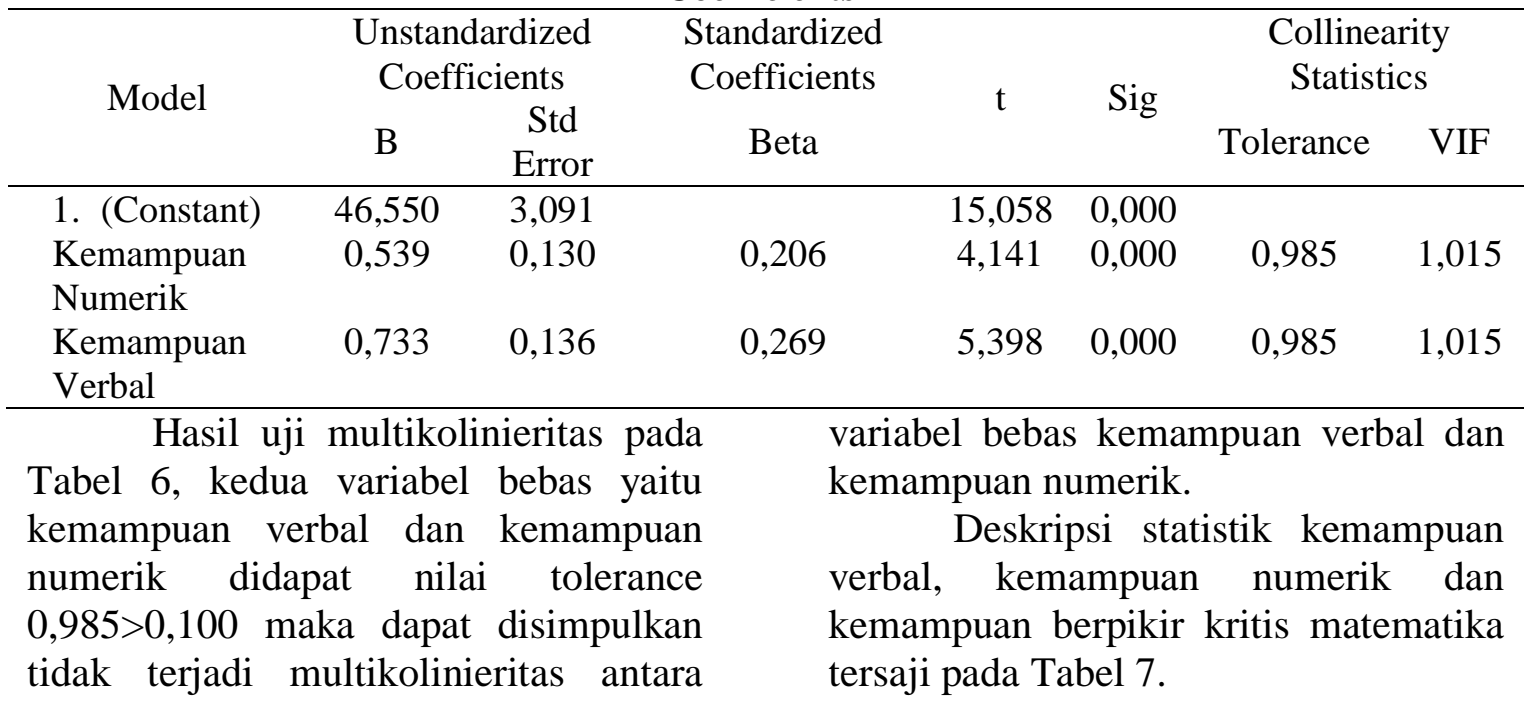


e-ISSN 2442-5419 Vol. 5, No. 2 (2016) 110-119

p-ISSN 2089-8703

Tabel 7. Hasil Deskripsi Data

\begin{tabular}{cccccc}
\hline & N & Minimum & Maximum & Mean & $\begin{array}{c}\text { Std } \\
\text { Deviation }\end{array}$ \\
\hline Kemampuan Numerik & 360 & 6 & 25 & 17,07 & 4,603 \\
Kemampuan Verbal & 360 & 6 & 25 & 17,33 & 4,414 \\
Kemampuan Berpikir Kritis & 360 & 40 & 90 & 68,46 & 12,040 \\
Matematika & & & & &
\end{tabular}

Dari Tabel 7 Di atas dapat terlihat nilai rata-rata kemampuan berpikir kritis matematika sebesar
68,46 . Sedangkan rata-rata kemampuan numerik dan kemampuan verbal berturut-turut adalah 17,07 dan 17,33.

Tabel 8. Hasil Uji Korelasi Ganda

Model Summary ${ }^{\mathrm{b}}$

\begin{tabular}{cccccc}
\hline Model & R & R. Square & Adjusted R Square & Std error of the Estimate & Durbin Watson \\
\hline 1 & 0,358 & 0,128 & 0,123 & 11,273 & 2,258
\end{tabular}

Koefisien korelasi ganda, yaitu antara kemampuan verbal dan kemampuan numerik terhadap kemampuan berpikir kritis matematika didapat angka $\mathrm{R}$ adalah 0,358 yang berarti terjadi hubungan yang tidak terlalu erat karena nilainya kurang dari 1.Koefisien determinasi sebesar 0,128 jika diubah kedalam bentuk persen maka 12,8\%, artinya persentase sumbangan pengaruh kemampuan verbal dan kemampuan numerik terhadap kemampuan berpikir kritis matematika sebesar $12,8 \%$. Sedangkan sisanya sebesar $78,2 \%$ dipengaruhi oleh variabel lain yang tidak dimasukan dalam penelitian ini.

Tabel 9. Hasil Pengujian Hipotesis

\begin{tabular}{cc} 
Hipotesis yang diuji & Signifikansi \\
\hline $\mathrm{X}_{1}$ terhadap Y & 0,000 \\
$\mathrm{X}_{2}$ terhadap Y & 0,000 \\
$\mathrm{X}_{1}$ dan $\mathrm{X}_{2}$ Secara bersama-sama terhadap Y & 0,000 \\
\hline
\end{tabular}

Berdasarkan Tabel 9 Di atas dapat dilihat nilai signifikansi pada masing-masing hipotesis lebih besar dari 0,05 maka dapat disimpulkan terdapat pengaruh yang signifikan antara kemampuan verbal dan kemampuan berpikir kritis matematika, terdapat pengaruh yang signifikan antara kemampuan numerik terhadap kemampuan berpikir kritis matematika, terdapat pengaruh secara bersama-sama kemampuan verbal dan kemampuan numerik terhadap kemampuan berpikir kritis matematika.

Tabel 10. Hasil Uji Regesi Ganda

\begin{tabular}{cccccc}
\multicolumn{5}{c}{ Anova $^{\mathrm{b}}$} \\
\hline Model & Sum of Squares & Df & Mean Square & F & Sig \\
\hline Regression & 6674,162 & 2 & 3337,081 & 26,261 & 0,000 \\
Residual & 45385,213 & 357 & 127,073 & & \\
Total & 52039,375 & 359 & & & \\
\hline
\end{tabular}




$$
\hat{Y}=46,550+0,539 X_{1}+0,733 X_{2}
$$

Dari persamaan regresi Di atas maka nilai konstanta (a) adalah 46,550 artinya jika kemampuan numerik dan kemampuan verbal bernilai nol maka kemampuan berpikir kritis matematika memiliki nilai positif yaitu 46,550. Selanjutnya nilai koefisesn regresi variabel bebas kemampuan numerik $\left(b_{1}\right)$ bernilai positif yaitu 0,539 artinya setiap peningkatan kemampuan numerik sebesar 1 akan meningkatkan kemampuan berpikir kritis matematika sebesar 0,539 dengan asumsi variabel lain bernilai tetap. Selanjutnya nilai koefisien regresi variabel kemampuan verbal $\left(b_{2}\right)$ bernilai positif yaitu 0,733 artinya setiap peningkatan kemampuan verbal sebesar 1 akan menningkatakan kemampuan berpikir kritis matematika sebesar 0,733 dengan asumsi variabel lain bernilai tetap.

Berdasarkan hasil penelitian yang telah dipaparkan, maka dapat dibuat suatu pembahasan dimana ternyata ada keterkaitan antara kemampuan verbal berupa kata-kata dengan kemampuan numerik terhadap kemampuan berikir kritis matematika. Kita ingat betul ketika kita masih tingkat sekolah dasar dimana ada suatu bilangan matematika 5.675 dituliskan dalam bentuk kata menjadi (lima ribu enam ratus tujuh puluh lima) hal ini jelas bahwa matematika bukan hanya saja berupa numerik simbol-simbol matematika semata namun harus lebih berarti sebagai kata yang mempunyai makna. Maka dari itu matematika tidak hanya condong pada satu memampuan yaitu numerik saja namun juga berkitan dengan kemampuan verbal dan dapat meningkatkan kemampuan berpikir kritis matematika.

Kemampuan verbal dan kemampuan numerik merupakan kemampuan bawaan yang sudah ada dari lahir sehingga tidak dapat ditingkatkan menjadi lebih tinggi karena ia merupakan kecerdasan bawaan akan tetapi kemampuan verbal dan kemampuan numerik dapat di optimalkan dengan cara banyak latihan berupa menyerap kosa kata baru dan banyak latihan untuk berhitung matematika karena dalam matematika hanya terdiri operasi hitung penjumlahan, pengurangan, perkalian dan pembagian. Oleh karena itu dengan mengoptimalkan kemampan verbal dan numerik maka akan meningkatkan kemampuan berpikir kritis matematika. Dalam kemampuan berpikir kritis matematika yaitu kemampuan untuk menganalisis dan memecahkan masalah dengan pengalaman yang dimilikinya. Dapat dikatakan pengalaman belajar merupakan salah satu nya adalah dengan latihan sehingga peningkatan kemampuan berpikir kritis matematikanya akan semakin tinggi. Menyadari pentingnya mengembangkan kemampuan berpikir kritis siswa sejak SD, maka mutlak diperlukan adanya pembelajaran matematika yang lebih banyak melibatkan siswa secara aktif dalam proses pembelajaran itu sendiri (Karim, 2011). Maka dari itu pembelajaran matematika tidak hanya melibatkan guru yang menjadi pusat pembelajaran namun lebih menitik beratkan keikut sertaan siswa dalam proses pembelajaran matematika. Pembelajaran yang melibatkan siswa akan membuat pembelajaran semakin hidup.

Kemampuan verbal dan kemampuan numerik adalah sebagian kecil dari berbagai hal yang dapat meningkatkan kemampuan berpikir kritis matematika siswa karena ada banyak faktor yang dapat meingktkan kemampuan berpikir kritis matematika siswa salah satunya adalah banyaknya latihan-latihan yang diberikan oleh guru 
sehingga siswa terbiasa mengerjakan dan memecahkan permasalahan matematika. Proses kemampuan berpikir kritis matematika pada siswa SMA hendaknya terus diasah agar dapat menjadi pemacu semangat ketika mereka belajar di perguruan tinggi karena memilki kemampuan berpikir kritis matematika minimal siswa dapat kemampuan kognitif untuk menganalisis, mengevaluasi dan mensintesis pemahaman yang sebelumnya telah mereka miliki.

Penguasaan kemampuan bahasa dalam matematika adalah saling keterkaitan. Karena matematika merupakan simbol-simbol yang bermakna, karena merupakan simbol maka perlu adanya pengenalan dalam bahasa karena dalam matematika dalam membaca simbol tersebut tidak dapat dipisahkan dengan bahasa. Kemampuan bahasa yang dimiliki seseoarang saling menunjang kemampuan numerik yang dimilkinya karena kemampuan berbahasa merupkan terjemahan dari simbol-simbol numerik dalam matematika.

Berpikir kritis dalam belajar matematika merupakan suatu proses kognitif seseorang dalam upaya memperoleh pengetahuan matematika berdasarkan penalaran matematik (Syahbana, 2012). Perlu adanya latihan yang terus dilakukan secara berkesinambungan sehingga menciptakan kemampuan yang signifikan.

Proses kemampuan berpikir kritis matematika perlu ditunjang dengan kemampuan untuk menganalisis dan mengevaluasi serta mensintesis pemahaman yang dimilkinya. Oleh karena itu kemampuan verbal dan numerik merupakan suatu keterkaitan yang dapat menunjang kemampuan berpikir kritis matematika. Dalam proses berpikir kritis matematika perlu adanya pemahaman dan kemampuan lebih dalam memproses pengetahuan dan kemampuan yang dimilikinya.

\section{KESIMPULAN DAN SARAN}

$\begin{array}{lcr}\text { Terdapat } & \text { pengaruh } & \text { yang } \\ \text { signifikan antara kemampuan } & \text { verbal } \\ \text { dan kemampuan numerik } & \text { secara }\end{array}$ bersama-sama terhadap kemampuan berpikir kritis matematika. Terdapat pengaruh yang signifikan antara kemampuan verbal terhadap kemampuan berpikir kritis matematia, Terdapat pengaruh yang signifikan antara kemampuan numerik terhadap keamapuan berpikir kritis matematika, sehingga diharapkan guru dan siswa dapat mengetahui bahwa kemampuan verbal dan numerik saling menunjang untuk peningkatan kemampuan berpikir kritis matematika.

Saran peneliti adalah guru dan siswa hendaknya dapat bersinergi untuk dapat mengetahui kemampuan berpikir kritis matematika dan mendalami faktor-faktor yang dapat mempengaruhi untuk meningkatkannya perlu mengetahui kemampuan numerik dan verbal yang dimilki oleh siswanya. Oleh karena itu, perlu adanya komunikasi yang baik antara pihak sekolah dengan pihak orang tua murid agar terciptanya kualitas pembelajaran yang efektif san efisien.

\section{DAFTAR PUSTAKA}

Astuti, Komang Ayu Ida. dkk. 2013. Pengaruh pendekatan matematika realistik terhadap prestasi belajar matematika ditinjau dari kemampuan numerik. Jurnal Pendidikan Dasar. Vol. 3, No. 2, Hal 64-78. 
Dona. 2010. Kemampuan Berpikir Kritis dan Kreatif. http:// donaafriyani.blogspot.com/.

Diakses 20 September 2016

Irawan, Ari. (2014). Pengaruh kecerdasan numerik dan penguasaan konsep matematika terhadap kemampuan berpikir kritik matematika.Jurnal Formatif.Vol. 4, No.1, Hal 4655

Karim, Asrul. 2011. Penerapan metode penemuan terbimbing dalam pembelajaran matematika untuk meningkatkan pemahaman konsep dan kemampuan berpikir siswa sekolah dasar.Prosiding Semnas Matematika Terapan, Edisi Khusus No. 1, Hal 21-32

Kumara, Amitya. 2001. Dampak kemampuan verbal terhadap ekspresi tulis. Jurnal Psikologi, Vol.1, No.1, Hal 35-40

Leonard. 2013. Peran Kemampuan berpikir kritis terhadap prestasi belajar matematika.Jurnal Mimbar Pendidikan Indonesia, Vol. 1, No. 2, Hal 61-71

Prahati.2011. Kemampuan Berpikir Kritis dan Kreatif Matematika.http://furahasekai.co m/2011/10/06/kemampuanberpikir-kritis-dan-kreatifmatematika/. Diakses 20 Semptember 2016.

Rosida, Halima dkk. 2002. Hubungan antara kemampuan awal dan kemampuan numerik dengan hasil belajar fisika siswa SMP. Journal Of Technology of EducationVol.13, No.2, Hal1215.
Saeful. 2014. Pengertian Kemampuan Numerik.http://www.pusattesis.c om/pengertian-kemampuannumerik/. Diakses 20 September 2016

Saregar, Antomi dkk.2011. Pembelajaran Fisika

Kontekstual Melalui Metode Eksperimen dan Demonstrasi Diskusi Menggunakan Multimedia Interaktif Ditinjau dari Sikap Ilmiah dan Kemampuan Verbal Siswa.http://portalgaruda.org/ind ex.php?ref=browse \&mod=viewa rticle \&article $=157585$. Diakses 20 September 2016

Simbolon, Naeklan. 2014. Pengaruh pendekatan pembelajaran dan kemampuan verbal terhadap kemampuan berbicara bahasa inggris siswa SMA Negeri 14 dan 21 Medan. Cakrawala Pendidikan. Vol.2, No.3, Hal 225-235.

Sumada, dkk.2013. Kontribusi kebiasaan belajar dan kemampuan numerikal terhadap hasil belajar matematika siswa kelas $V$ SD Negeri Seraya Timur. http://portalgaruda.org/?ref=bro wse \&mod=viewarticle $\&$ article $=$ 105766. Diakses 20 September 2016

Syahbana, Ali. 2012. Peningkatan kemampuan berpikir kritis matematis siswa smp melalui pendekatan contextual teaching and learning. EDUMATICA (Journal Pendidikan Matematika), Vol.2, No.1,Hal 45-57 